\title{
Tax Revenue As An Automatic Fiscal Stabiliser - A South African Perspective
}

\author{
A S Swanepoel \\ South African Reserve Bank
}

\section{N J Schoeman}

Department of Economics, University of Pretoria

\section{ABSTRACT}

The many practical economic and political difficulties encountered in discretionary fiscal stabilisation policy highlight the potential benefits of allowing automatic fiscal stabilisers to operate over the cycle. This article investigates the relevance of tax revenue as an automatic fiscal stabiliser in the South African economy by an empirical analysis of its role and impact since the 1970s. The study finds that cyclical changes in tax revenue are relatively small and provide no significant evidence of automatic stabilisation; however, the potential of this tool as an effective automatic fiscal stabiliser in South Africa cannot be overlooked as results show a high correlation between the output gap and automatic stabiliser estimates. Automatic fiscal stabilisers were employed symmetrically over the cycle and results showed that automatic fiscal stabilisers became increasingly important towards the end of the sample period.

JEL C10, E32, E63, H29

\section{INTRODUCTION AND BACKGROUND}

The way in which the government allocates its spending, collects its taxes and finances its deficit has important implications for the economy. Since 1984, consolidated general government expenditure in South Africa accounts for more than 30 per cent of the gross domestic product (GDP), while the average ratio of general government employment to total non-agricultural employment for the preceding nine fiscal years also exceeded the 30 per cent mark. The South African government is therefore a key economic player that can influence total economic activity and employment by changes in government spending and/or influence the amount of money individuals and firms have to spend on consumption and investment by changing the level of taxation. Consequently, increased spending or lower taxes tend to boost the economy, while decreased spending and higher taxes tend to have the opposite effect in true Keynesian tradition. 
This article highlights the fiscal policies pursued by the South African government since the 1970 s with specific reference to the role of taxes in stabilisation policy. The main focus is on the magnitude and composition of general government tax revenue and its role and potential as an automatic fiscal stabiliser in South Africa. No attempt is made to assess the efficiency of fiscal actions. The scope of this paper also does not extend to an evaluation of monetary policy or the linkages between monetary policy and fiscal policy.

Section 2 discusses fiscal stabilisation policy with reference to discretionary and non-discretionary fiscal policy. The many practical economic and political difficulties encountered in discretionary fiscal stabilisation policy highlight the importance and benefits of automatic fiscal stabilisers. Section 3 documents the main factors that influence the size of automatic fiscal stabilisers. Some aspects of South African fiscal policy are discussed in Section 4 while Section 5 evaluates the role of general government tax revenue as an automatic fiscal stabiliser in South Africa since the 1970s. Section 6 concludes and draws policy implications.

\section{FISCAL STABILISATION POLICY}

The use of fiscal policy as a stabilisation tool is difficult. There are many factors that contribute to the frequent divergence of fiscal and economic outcomes of government plans. These factors include, for example:

\footnotetext{
- the uncertainty regarding the impact of fiscal measures;

- the uncertainty as to the present and anticipated economic conditions;

* the lag between fiscal decisions and their implementation;

- the possibility of conflict between political and fiscal policy objectives; and

- the complexity of intergovernmental financial relations.
}

Fiscal instruments have behavioral and structural consequences and their use for stabilisation purposes may conflict with tax-smoothing and efficiency objectives. The government's budget has many purposes besides stabilisation and much of government spending is committed years or even decades in advance. Expanding or contracting government expenditure rapidly for macroeconomic stabilisation purposes is therefore difficult without either spending wastefully or compromising other fiscal policy goals. The same applies to taxes. Taxes are somewhat easier to change, but the tax laws also have many different goals. 
The main difference between discretionary and non-discretionary fiscal policy is that non-discretionary fiscal policy does not involve any deliberate government action, while discretionary fiscal policy can be defined as a deliberate attempt by government to obtain a certain objective. Automatic (or built-in) stabilisers are types of automatic fiscal policies that do not require new legislation, because economic conditions cause government revenue and expenditure to change without any deliberate government action.

\subsection{Problems with Discretionary Fiscal Policy}

There are many practical economic and political difficulties encountered in discretionary fiscal stabilisation policy. Governments find it easier to increase spending in times of low growth than to reduce expenditure and tighten fiscal policy during economic upturns. According to the European Central Bank (2002: 36), this induces a tendency for continuous increases in deficits and the tax burden. Furthermore, it is difficult to determine the appropriate size of the annual deficit, while fiscal adjustments and their effects are also subject to variable and unpredictable time lags. As a result, governments' well-intended efforts to stabilise the economy often end up destabilising it, "booming the boom" or "depressing the depression". Proper timing of discretionary policy is both extremely difficult to achieve and extremely crucial if it is to help the economy.

There is also the growing realisation that high budget deficits could directly or indirectly crowd out relatively more productive private sector activity such as investment. Moreover, discretionary policy presents a dilemma when low levels of economic activity coincide with high inflation and balance of payments deficits such as the case in South Africa during the latter half of the 1970s (Heyns, 1999: 70). According to the European Commission (1997: 109), the efforts to support the economy during downtums in EU countries have often been made through expenditure commitments that have subsequently proven de facto irreversible. This resulted in an upward "ratchet" effect on the size of the public sector in the economy, on both the tax and the expenditure side.

The attempts of discretionary fiscal policy to stabilise the economy therefore run into some technical problems. The ability to measure and analyse the economy is imperfect; gauging how far the economy is from full employment at any particular time is difficult. Furthermore, the amount that output will increase in response to a fiscal expansion is not known exactly, making it difficult to assess how much of a fiscal change is needed to restore full employment. Because macroeconomic policies take time to implement and more time to affect the economy, their optimal use requires knowledge of where the economy will be in six or twelve months from now. Such knowledge is, at best, very imprecise. 
Against this background, most economists have become highly sceptical about the potential benefits of "fine tuning" the economy. While there is generally broad agreement on the usefulness of allowing automatic stabilisers to operate over the cycle, there is a large literature dealing with the pros and cons of attempting stabilisation through discretionary measures. The combined problems of lags, crowding out effects, political constraints, inflexibility and practical problems in measuring and forecasting the state of the economy and determining how much fiscal stimulus is needed at any particular point in time all present very serious challenges for discretionary fiscal policy to have the desired effect on stabilisation.

\subsection{Taxes as Tools for Stabilisation}

Automatic fiscal stabilisers get around these problems because economic conditions cause government expenditure and revenue to change without any deliberate government action, ensuring that they can act in a much quicker and timelier fashion compared to the use of discretionary measures. Tax receipts weaken and social transfers increase, for example, during recessions and show reversed movements during expansions. These changes in the budget balance that are induced by cyclical fluctuations, in turn have a stabilising influence on economic activity. These budgetary automatic stabilisers contribute to a stimulation of the economy in a period of recession and exert a dampening effect in periods of overheating, and should therefore be automatically selfcorrecting. Governments have the option to either let these automatic stabilisers work or to reinforce or restrain their effect via discretionary budgetary policy. During a recession, governments might prefer not to let the budget deficit deteriorate due to the operation of the automatic stabilisers and will therefore decide to conduct a procyclical budgetary policy, or they might choose to actively undertake a counter-cyclical budgetary policy which will further increase the deficit.

Taxes are used for stabilisation purposes either by way of discretionary tax rate changes or via their built-in stabilisation properties. Fluctuations in revenue usually account for a much larger share of automatic stabilisers than fluctuations in expenditure. According to the OECD (1993: 44), tax-based automatic stabilisers have the advantage that they are rule-based because they respond immediately to changes in activity and generate expectations of future reversals that may limit the impact of greater public borrowing on long-term interest rates. If the economy goes into recession because of a sudden drop in autonomous consumption, for example, the progressive taxes drop even faster than income, and this decrease in taxes has a multiplier effect, partly offsetting the drop in autonomous consumption, so that equilibrium income does not drop as far or as fast as it possibly could. According to Abel and Bernanke (2001: 572), this 
automatic tax cut helps cushion the drop in disposable income and prevents aggregate demand from falling during recessions, making fiscal policy automatically more expansionary. On the other hand, when people's income rise during a boom, the government collects more income tax revenue, which helps restrain the increase in aggregate demand.

In summary, automatic stabilisers help to smooth out fluctuations in the business cycle by automatically moving the budget toward a deficit during recession and toward a surplus during an expansion. Automatic fiscal stabilisers like the income-based tax system can play a prominent role in converting some periods of likely recession into periods of normal growth as well as in boosting growth in the first year following recession troughs. By preventing sharp economic fluctuations, fiscal stabilisers may enhance long-term economic performance and avoid frequent changes in spending or tax rates (Van den Noord, 2000: 2).

\section{FACTORS INFLUENCING THE SIZE OF AUTOMATIC FISCAL STABILISERS}

According to the European Commission (1997: 95), the magnitude of budgetary automatic stabilisers is quite important for most of the EU Member States and varies substantially across countries and over time. The size of automatic fiscal stabilisers is important for budget planning and for the assessment of progress towards fiscal targets throughout the cycle.

\subsection{Size of Government}

The size of automatic fiscal stabilisers varies with the importance of the government sector in the economy. The higher the share of tax revenue in the economy, the greater is the sensitivity of government income to fluctuations in GDP. The OECD (1993: 37) argues that the size of the public sector relative to GDP is the most important element in determining the extent of the automatic stabilisers.

\subsection{Tax Structure and the Sensitivity of Tax Revenues to the Cycle}

The size of automatic fiscal stabilisers also depends on the budget's sensitivity to the cycle (OECD, 1999: 138). The sensitivity of budget receipts to cyclical fluctuations differs depending on the revenue category. For example, corporate taxes paid by the business sector vary most with the cycle due to the sensitivity of profits to cyclical fluctuations, while social contributions vary less with the cycle due to the regressive nature of this tax. The cyclical sensitivity of personal income taxes and indirect taxes is situated between these two extremes. Based 
simply on the relative size of its fluctuations, the corporate income tax can be a potentially important source of automatic stabilisation (Auerbach \& Feenberg, 2000: 18). According to the OECD (1993: 44), the extent of the cyclical fluctuation in government revenue depends on two factors: i) the size of the initial level of taxation (the average tax rate); and ii) the elasticity of taxation with respect to changes in output (the marginal tax rate). Furthermore, the cyclical behaviour of tax yields may be changing over time due to reforms of tax systems. For example, reform initiatives that flatten personal tax rate structures reduce the automatic stabilising properties of tax systems. The response of tax bases to changes in activity may also depend on the nature of the economic shock(s) that produced the boom or recession. Cohen and Follette (2000: 40) maintain that higher income tax rates represent stronger automatic stabilisers.

The progressivity of the tax system is an important factor in determining the size of automatic stabilisers (Van den Noord, 2000: 4). Government revenue fluctuates with slightly greater amplitude than fluctuations in output. In part, this stems from the difference between the average and the marginal rates of taxation on labour income. Such a difference means that when average income per person employed falls during a recession, either through a fall in overtime work or through a fall in wages, the drop in government revenue is more rapid than that of average incomes.

The OECD (1993: 37) maintains that the structure of the tax system has a significant impact on the size of automatic stabilisers. The higher the average tax rate on income from a cyclically sensitive source, the larger will be the automatic stabiliser. For example, taxation is lost when an employee is made redundant. In this case, the amount of stabilisation depends on the average tax rate on labour income (defined as wage income plus social security contributions). Van den Noord (2000: 7) also argues that the tax structure has a significant impact on the size of automatic stabilisers. The higher the taxation of cyclically sensitive tax bases, the more the tax take will vary with the business cycle and hence the greater will be the cyclical sensitivity of the fiscal position. Apart from differences in tax rates and tax structures, the distribution of income also influences the size of automatic fiscal stabilisers. According to Auerbach and Feenberg (2000: 12 ), severai authors have estimated that the income of lower-income individuals is more cyclically sensitive to macroeconomic conditions, as measured by fluctuations in aggregate income or the unemployment rate. 


\subsection{The Effectiveness of Stabilisation Efforts in Relation to the Openness and Structure of the Economy}

The dampening effect of automatic stabilisers on output fluctuations differs significantly across countries. It depends among others on the degree of openness of the economy and on the structure of tax and expenditure systems. According to Barrell and Pina (2000: 23), openness - often inversely related to economic size - counters the effectiveness of budgetary stabilisers. The European Commission (1997: 99) argues that in the open economies of the smaller EU member states, the impact of the automatic stabilisers on output fluctuations can be expected to be relatively modest because of the importance of the trade leakages, which reduce the domestic effectiveness of fiscal policy. In the more closed economies of the larger EU member states, the dampening effect of the operation of the automatic stabilisers should be more significant. The more open countries therefore need, ceteris paribus, comparatively larger budgetary fluctuations in order to achieve the same degree of output smoothing as obtained in the more closed economies, which have automatic stabilisers of a smaller size.

The effect of automatic stabilisers on activity can be significant or almost nonexistent depending on the structure of the economy (OECD, 1993: 42). The degree of stabilisation provided depends on the same factors that influence tax and expenditure multipliers following discretionary changes in fiscal policy: trade flows, savings reactions and the degree of flexibility in labour and product markets.

\subsection{Fiscal Restraints}

Eichengreen (1997: 94) states that there is empirical as well as counterfactual evidence that governments operating under Maastricht-type restrictions engage in significantly less automatic stabilisation. Governments with relatively strict restrictions on deficits and debt are found to stabilise the least. Governments operating under relatively stringent fiscal restrictions carry out significantly less fiscal stabilisation due to reductions in the cyclical sensitivity of their spending.

\subsection{The Relationship between Automatic and Discretionary Stabilisation}

The overall degree of fiscal stabilisation reflects both the operation of the stabilisers themselves and their influence on, and interaction with, discretionary policies (OECD, 1999: 141). Thus, if automatic stabilisers are overridden by discretionary adjustments, their impact will be neutralised. On the other hand, if they are reinforced by discretionary adjustments, the overall fiscal impulse will be stronger. 
It is important to note that larger automatic stabilisers are not necessarily preferable. Large automatic fiscal stabilisers may indicate high tax burdens, highly distorting tax rates or overly generous benefit systems fraught with potentially large deadweight costs that can delay adjustment to a changing economic environment (Tam \& Kirkham, 2001: 5 and European Central Bank, 2002: 35 ).

\section{FISCAL POLICY IN SOUTH AFRICA}

\subsection{Some Aspects of Fiscal Policy in South Africa}

Fiscal policy in South Africa during the 1970s and early 1980s centered around demand management, including frequent variations in the size of the national budget deficit in the interest of macroeconomic stability in the relationship between growth, inflation and the balance of payments (Heyns, 1999: 69). According to Heyns (1999: 70), official stabilisation policy in South Africa during the 1970s was premised on the Keynesian requirement of flexibility and the assumption that government could and should influence the level of economic activity through short-term fiscal adjustments in spending and taxes. Heyns (1999: 73) states that the automatic response of tax yields on economic activity was an important ingredient of the national budget's total influence on the national economy. The government used discretionary policy action during the 1970 s mainly to smooth out automatic fluctuations in government deficits (Heyns, 1999: 74). Heyns (1995: 309) argues that since the 1980s, the focus of South African budgetary policy has increasingly shifted from the earlier Keynesian emphasis on short-term stabilisation to the longer-term implications of the budget.

After several years of consolidation, bringing the national govemment budget deficit down to 1.5 per cent of GDP in the fiscal year 2001/2002, fiscal policy in South Africa is now decidedly growth-orientated. The 2001 Budget paved the "ay for a growth-orientated fiscal policy stance of improved spending, sigmficam increases in infrastructure allocations and ongoing tax reform, within the sound framework of liscal management established over the last six years (Soutl African National Treasury, Budget Review, 2001: 1). The 2001 Budget had a renewed focus on microeconomic and structural reforms. The belief was that the series of growth-orientated microeconomic reforms would complement and sharpen the broader structural changes that have taken place through the economy. The 2002 Budget reinforces the growth-orientated stance of the previous Budget (South African National Treasury, Budget Review, 2002: 1). 
The South African government's medium-term fiscal programme, adopted in 1994, operates within the parameters of the government's strategy on growth, employment and redistribution (GEAR). The government presented GEAR in 1996 , as a non-negotiable policy document confirming that the country had embarked on an outward orientated economic growth and development path that shows strong correspondence with good international practice. The belief was that sustained growth on a higher plane requires a transformation towards a competitive outward-orientated economy.

The GEAR strategy maintains that the main goal of fiscal policy since 1993, has been to achieve an annual reduction in the budget deficit of about 0.5 per cent of GDP, together with a reduction in government consumption expenditure and avoidance of permanent increases in the tax burden. It is also envisaged that there should be an increase in public sector investment spending. GEAR emphasised a systematic reduction of the Budget deficit to reduce government dissaving as a means towards higher economic growth. It is clear from Table 1 that the South African government succeeded in reducing the government deficit as a ratio of GDP since the publication of the GEAR document. As a result, government dissaving as a ratio of GDP also decreased from 6.1 per cent in fiscal 1992/93 to 0.4 per cent in fiscal 1999/2000.

Table 1 Projected and actual fiscal deficit as a ratio of GDP, 1996-2000 (Per cent)

\begin{tabular}{|l|c|c|c|c|c|c|}
\hline Deficit & 1996 & 1997 & 1998 & 1999 & 2000 & Average \\
\hline Projected & 5.1 & 4.0 & 3.5 & 3.0 & 3.0 & 3.7 \\
\hline Actual & 5.1 & 5.0 & 3.7 & 2.8 & 2.3 & 3.8 \\
\hline
\end{tabular}

Source: GEAR and South African Reserve Bank

With discretionary fiscal policy embedded in the philosophy of the GEAR document, the objectives were stated as a drive towards international competitiveness and minimising the distorting effects of taxation on economic behaviour, while preserving the fundamental progressiveness of the overall tax structure. The objective for the ratio of tax to GDP is set at about 25 per cent. The GEAR document argues that the combined effect of recent tax reforms has probably been roughly neutral with respect to the overall burden. Several measures have had a favourable impact on the distortionary effects of the tax system, while the overall tax incidence has remained progressive.

On the expenditure side of the budget it should be remembered that South Africa is a developing country with huge disparities in income and standards of living in general. Instead of stabilising the business cycle, expenditure is dedicated 
towards addressing these social disparities. With regard to income tax (the largest tax component), average and marginal rates are highly progressive and there is much more room for automatic stabilisation.

Over the past few years, there has been a strong focus on improving the capacity of the tax authorities and the establishment of a more independent revenue service was an important step. Section 3.5 of the GEAR document states that an improvement in economic growth, together with improved tax administration, should lead to a strong increase in tax revenue relative to GDP. Improved tax administration did in fact contribute significantly to higher tax revenue (South African Reserve Bank Annual Economic Report, 2000: 84). But how much did other factors, including automatic fiscal stabilisers, contribute towards this achievement? This question will be addressed in Section 5 .

\subsection{Trends in General Government Tax Revenue in South Africa}

Data on the consolidated general government tax revenue was obtained from the South African Reserve Bank's database. The South African Reserve Bank classifies government finances in its Quarterly Bulletin according to the IMF's A Manual on Government Finance Statistics (1986). South Africa's consolidated general government comprises three levels of government, namely the consolidated central government,' provincial government and local authorities.

Taxes on income and profits and domestic taxes on goods and services are the most important categories of direct and indirect tax revenue respectively. From Table 2 it is clear that direct taxes are the main source of South African revenue, averaging 54.4 per cent of total tax revenue over the sample period. Indirect tax as a ratio of total tax revenue, reached a maximum of 51.9 per cent in fiscal $1993 / 94$ before declining to 47.0 per cent in fiscal $2000 / 01$. As a ratio of gross domestic product, the highest value of 12.9 per cent was recorded in fiscal 1989/90. This was the result of stronger collections from taxes on goods and services. The improvement in the ratios of direct tax revenue and total tax revenue to gross domestic product during the last three fiscal years can partly be ascribed to better management and the implementation of more efficient practices and procedures by the South African Revenue Service.

Table 3 indicates that taxes on net income and profits are the main source of consolidated general government revenue. During fiscal 1974/75, more than half of total revenue could be ascribed to taxes on income and profits. This ratio decreased slightly to the lowest value of 41.2 per cent in fiscal $1993 / 94$ before increasing again to 47,0 per cent in fiscal $2000 / 01$. 
Table 2 Components of consolidated general government tax revenue

\begin{tabular}{|c|r|r|r|r|r|r|r|r|}
\hline \multirow{2}{*}{$\begin{array}{c}\text { Fiscal } \\
\text { years }\end{array}$} & \multicolumn{3}{|c|}{ Direct tax } & \multicolumn{3}{c|}{ Indirect tax } & \multicolumn{3}{c|}{ Total tax } \\
\cline { 2 - 9 } R billions $\%$ Total & $\%$ GDP & R billions $\%$ Total $\%$ GDP & R billions & \%GDP \\
\hline $\mathbf{1 9 7 4 / 7 5}$ & 3.2 & 66.7 & 12.8 & 1.6 & 33.3 & 6.3 & 4.8 & 19.2 \\
\hline $\mathbf{1 9 7 9 / 8 0}$ & 5.8 & 57.1 & 11.5 & 4.4 & 42.9 & 8.7 & 10.2 & 20.2 \\
\hline $\mathbf{1 9 8 4 / 8 5}$ & 14.0 & 54.2 & 12.2 & 11.8 & 45.8 & 10.3 & 25.8 & 22.5 \\
\hline $\mathbf{1 9 8 9 / 9 0}$ & 34.3 & 50.5 & 13.2 & 33.7 & 49.5 & 12.9 & 68.0 & 26.1 \\
\hline $\mathbf{1 9 9 3 / 9 4}$ & 51.1 & 48.1 & 11.6 & 55.2 & 51.9 & 12.5 & 106.4 & 24.1 \\
\hline $\mathbf{1 9 9 9 / 0 0}$ & 116.8 & 52.9 & 14.2 & 104.0 & 47.1 & 12.7 & 220.8 & 26.9 \\
\hline $\mathbf{2 0 0 0 / 0 1}$ & 127.6 & 53.0 & 14.0 & 113.1 & 47.0 & 12.4 & 240.7 & 26.4 \\
\hline
\end{tabular}

Source: South African Reserve Bank

Over time, the tax burden has shifted away from mines and corporations towards individuals. The share of taxes on goods and services increased noticeably from below 20 per cent at the beginning of the sample period to 30.6 per cent at the end of the sample period. Taxes on international trade and transactions increased in nominal terms after South Africa's reintroduction to international markets. Social security contributions also increased noticeably since the latter half of the sample period. As illustrated in Figure 1, tax revenue became increasingly important towards the end of the sample period, while the opposite holds for non-tax revenue. According to Blanchard (2000: 71), an increasing share of taxes and transfers in GDP suggests an increase in automatic stabilisers. The next section will explore this issue, and more particularly the role of tax revenue as an automatic fiscal stabiliser in South Africa.

Table 3 Consolidated general government tax revenue, share of total revenue (per cent)

\begin{tabular}{|c|c|c|c|c|c|c|c|c|}
\hline $\begin{array}{l}\text { Fiscal } \\
\text { years }\end{array}$ & $\begin{array}{c}\text { Taxes on } \\
\text { het incoms } \\
\text { \& profits }\end{array}$ & $\begin{array}{c}\text { Taxes } \\
\text { on } \\
\text { property }\end{array}$ & $\begin{array}{c}\text { Taxes on } \\
\text { goods and } \\
\text { services }\end{array}$ & $\begin{array}{c}\text { Taxes on } \\
\text { int, trade } \\
\text { \& trans- } \\
\text { actions }\end{array}$ & $\begin{array}{c}\text { Other } \\
\text { taxes }\end{array}$ & $\begin{array}{c}\text { Social } \\
\text { sec.contri- } \\
\text { butions }\end{array}$ & $\begin{array}{c}\text { Taxes } \\
\text { on } \\
\text { payroll }\end{array}$ & $\begin{array}{c}\text { Tax } \\
\text { reve- } \\
\text { nue }\end{array}$ \\
\hline $\mathbf{1 9 7 4 / 7 5}$ & 50.6 & 5.9 & 13.5 & 4.2 & 3.1 & 1.1 & 0.3 & 78.5 \\
\hline $\mathbf{1 9 8 4 / 8 5}$ & 43.6 & 4.9 & 27.2 & 2.1 & 2.5 & 1.0 & 0.2 & 81.4 \\
\hline $\mathbf{1 9 9 3 / 9 4}$ & 41.2 & 6.2 & 31.6 & 3.8 & 1.6 & 1.7 & 0.0 & 86.0 \\
\hline $\mathbf{2 0 0 0 / 0 1}$ & 47.0 & 5.2 & 30.6 & 2.7 & 2.2 & 1.6 & 0.5 & 89.7 \\
\hline
\end{tabular}

Source: South African Reserve Bank. 
Figure 1 Consolidated general government tax and non-tax revenue as a ratio of gross domestic product

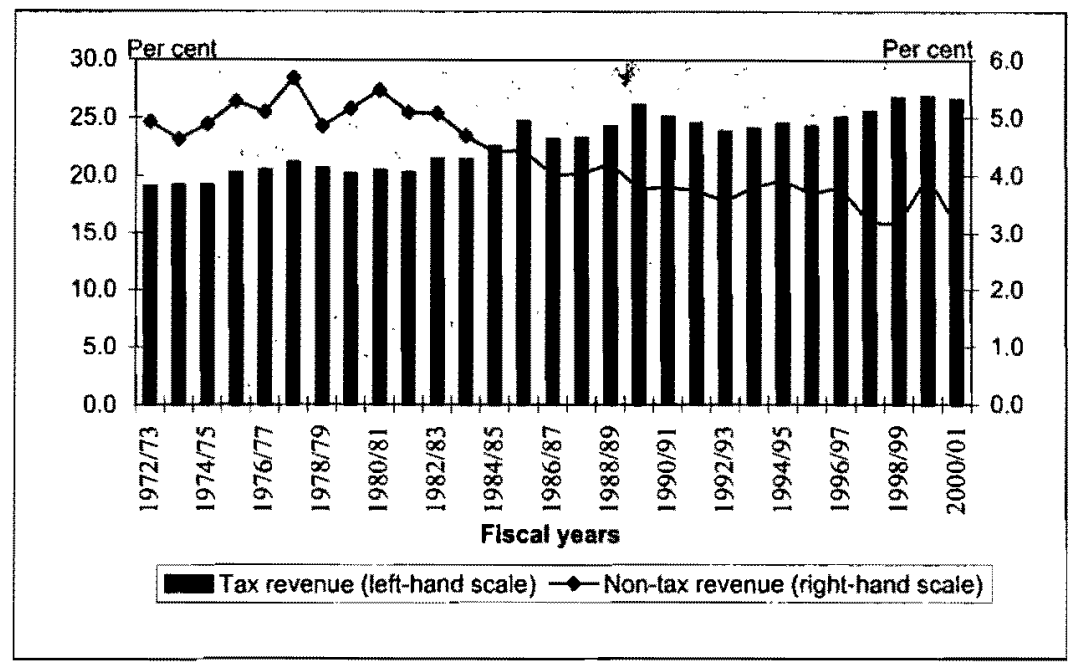

\section{THE ROLE OF TAX REVENUE AS AN AUTOMATIC FISCAL STABILISER IN SOUTH AFRICA}

The cyclical component of general government tax revenue is calculated by subtracting the estimated structural component from its actual level. Structural tax revenue is calculated from actual tax revenue, adjusted proportionately, according to the ratio of potential output to actual output and corresponding elasticity assumptions (see Giono et al, 1995: 191). This can be illustrated as:

$$
\frac{T_{i}^{*}}{T_{i}}=\left(\frac{Y^{*}}{Y}\right)^{a_{*}}
$$

where: $T_{i}^{*}=$ structural tax revenue for the $i^{\text {th }}$ category of tax

$T_{i}=$ actual tax revenue for the $i^{\text {th }}$ category of tax

$Y=$ level of actual output

$Y^{*}=$ level of potential output

$\alpha_{i}=$ elasticity of the $i^{\text {th }}$ tax category with respect to output.

Potential output was estimated by the GDP smoothing approach using a Hodrick-Prescott $(\mathrm{HP})$ filter (lambda $=100)^{2}$. According to Cerra and Saxena (2000: 4), trend output $\left(y^{*}\right)$ derived using the HP filter is obtained by 
minimising a combination of the gap between actual output $(y)$ and trend output and the rate of change in trend output for the whole sample of observations (T):

$$
\operatorname{Min} \sum_{i=0}^{T}\left(y_{t}-y_{t}^{*}\right)^{2}+\lambda \sum_{i=2}^{T-1}\left[\left(y_{i+1}^{*}-y_{i}^{*}\right)-\left(y_{i}^{*}-y_{i-1}^{*}\right)\right]^{2}
$$

where the detrending parameter $\lambda$ determines the degree of smoothness of the trend.

The sensitivity of tax revenue categories with respect to GDP $\left(\alpha_{i}\right)$ is captured in the form of an elasticity and these elasticities were assumed to remain constant over the cycle. Elasticities were calculated using a simple regression of each tax category ( $T_{i}$ ) on output $(Y)$ (in current prices). ${ }^{3}$ The results of this approach, estimated using data from fiscal 1969/70 to 1999/2000 are shown in Table 4.

Table 4 Tax elasticity estimates

\begin{tabular}{|l|c|}
\hline \multicolumn{1}{|c|}{ Tax category } & Elasticity \\
\hline Taxes on net income and profits & 1.04 \\
\hline Taxes on property & 1.02 \\
\hline Taxes on goods and services & 1.24 \\
\hline Taxes on international trade and transactions & 0.94 \\
\hline Other taxes & 0.84 \\
\hline Social security contributions & 1.24 \\
\hline Employer's payroll and manpower taxes & 0.45 \\
\hline Total tax revenue & 1.08 \\
\hline Direct tax & 1.03 \\
\hline Indirect tax & 1.14 \\
\hline
\end{tabular}

Most of the coefficients reported in Table 4 are unitary or larger, meaning that some increase proportionally with GDP while others increase more than proportionally with GDP. This reflects the built-in elasticity of the South African tax structure that can generate an increasing tax effort if no discretionary tax measure is used to offset this effect. The marginal sensitivity of budgetary receipts to GDP can be obtained by multiplying the overall revenue elasticity by the tax to GDP ratio (European Commission 1997: 97). The average marginal sensitivity of general government revenue estimated at 0.2 for South Africa, indicate that each widening of a negative output gap by 1 percentage point reduces general government revenue in South Africa by 0.2 percentage points of GDP.

Figure 2 illustrates South African real GDP, the trend in real GDP derived using the Hodrick-Prescott filter, and the GDP gap measured as the percentage deviation of observed real GDP from trend real GDP. Over the years, economic 
activity was volatile in terms of large and persistent deviations from trend as measured by the output gap.

\section{Figure 2 Actual real GDP, trend real GDP and the output gap}

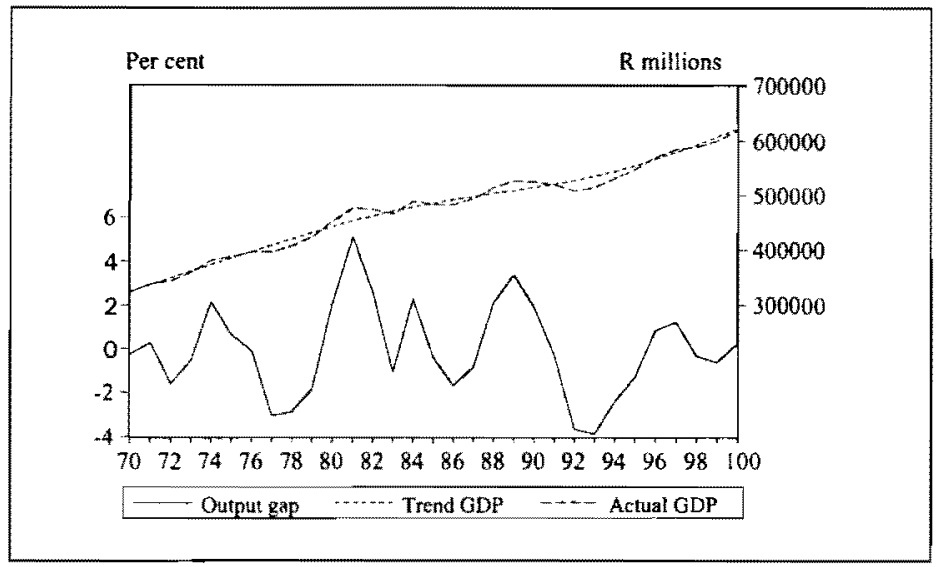

Table 5 Size and volatility of the output gap and the cyclical component of general government tax revenue

\begin{tabular}{|l|c|c|c|c|c|}
\hline & \multirow{2}{*}{$\begin{array}{c}\text { Volatility } \\
\text { stand. dev. }\end{array}$} & \multicolumn{2}{|c|}{$\begin{array}{c}\text { Lowest negative } \\
\text { component }\end{array}$} & \multicolumn{2}{c|}{$\begin{array}{c}\text { Highest positive } \\
\text { component }\end{array}$} \\
\cline { 3 - 7 } & $\begin{array}{c}\text { coints of } \\
\text { GDP) }\end{array}$ & $\begin{array}{c}\text { Value (as \% } \\
\text { of GDP) }\end{array}$ & Year & $\begin{array}{c}\text { Value (as \% } \\
\text { of GDP) }\end{array}$ & Year \\
\hline Cyclical \\
component & 0.3 & -0.9 & 1993 & 0.5 & 1989 \\
\hline Output gap & 2.1 & -3.9 & 1993 & 5.1 & 1981 \\
\hline
\end{tabular}

The standard deviation of the cyclical component of tax revenue may be useful as a rough indicator of how sensitively it responds to the business cycle. General government tax revenue show less marked deviations than the business cycle as a whole. Table 5 shows that the cyclical component and the output gap on average varies with around 0.3 and 2.1 percentage points of GDP respectively in either direction around their means. The lowest negative values for the cyclical component and the output gap were recorded in 1993, while the highest positive values for the output gap and the cyclical component were recorded in 1981 and 1989 respectively. The actual, structural and cyclical part of general government tax revenue (as a ratio of trend GDP) is shown in Figure 3 . 
Figure 3 Comparison of actual, structural and cyclical tax revenue as a ratio of trend GDP

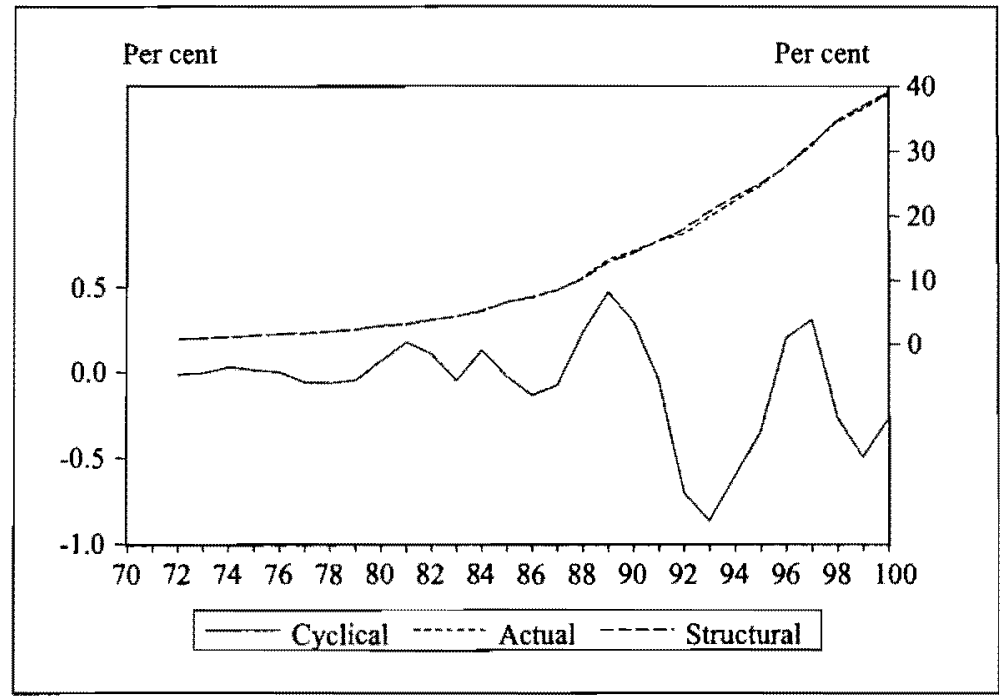

Figure 4 Cyclical tax revenue and the output gap

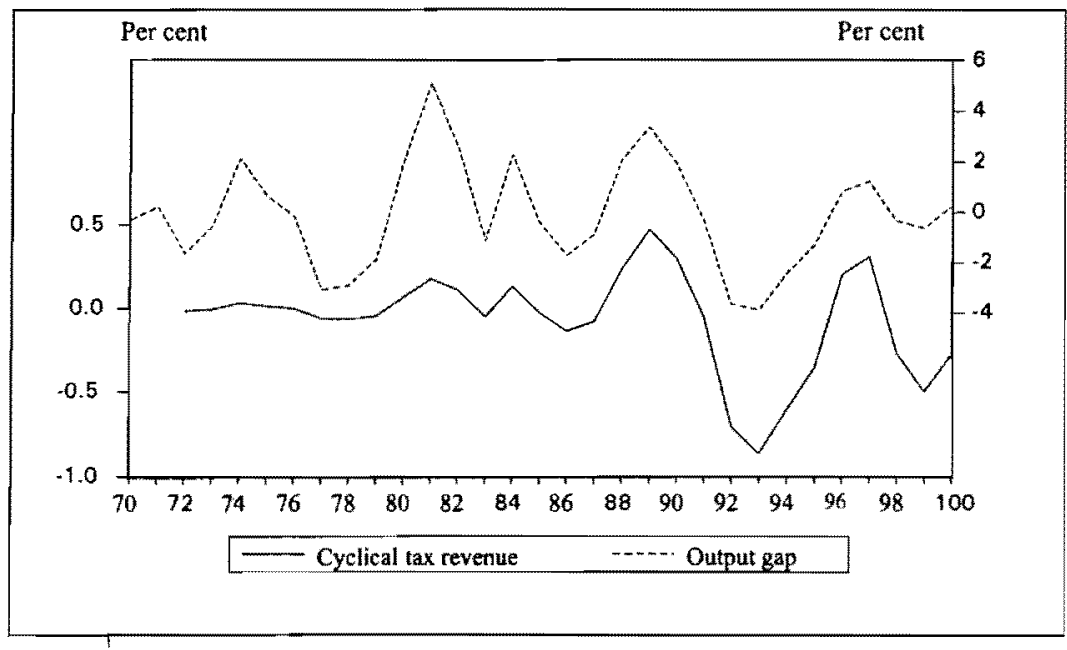

The high correlation between the output gap and the cyclical component of general government tax revenue is clear from Figure 4. Tax revenue responds more or less in line with changes in the output gap and it seems as if the 
automatic fiscal stabilisers associated with the tax system in South Africa were allowed to operate in both the up and down sides of the cycle. The results also illustrate a more prominent role of automatic fiscal stabilisers during the latter half of the sample period.

\section{Figure 5 Sensitivity of cyclical tax revenue with respect to alternative tax elasticities}

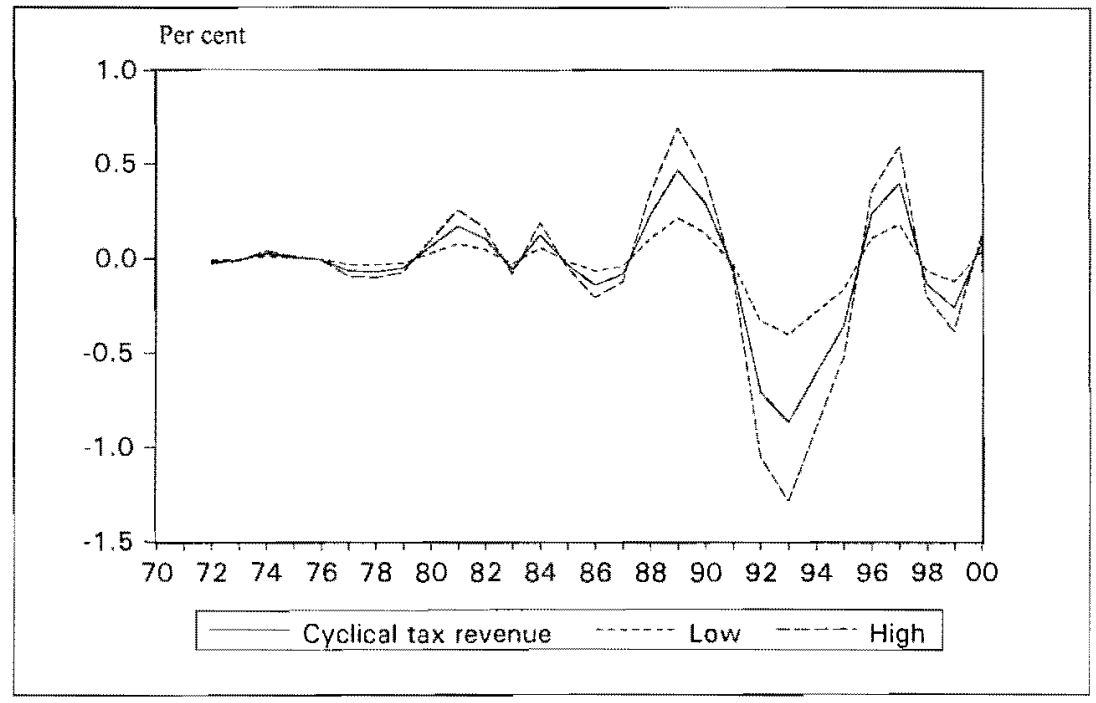

The sensitivity of automatic stabiliser estimates to assumptions determines their usefulness in policy making (Tam \& Kirkham, 2001: 11). Alternative assumptions change the level of estimated stabilisers making it difficult to accurately assess what the state of government finances is at a given point in time. However, a consistent trend makes it possible to state whether the structural position is improving or deteriorating. A sensitivity analysis with respect to the automatic fiscal stabiliser estimates was carried out by means of alternative assumptions of the elasticity of tax revenue, adjusted 50 per cent either way from the current estimate. Figure 5 shows that the calculation of automatic fiscal stabilisers associated with general government tax revenue in South Africa is relatively robust with respect to alternative assumptions of tax elasticities. The maximum or minimum value for the alternative assumptions resulted in a maximum difference of 0.5 per cent of GDP.

Taylor (2000: 33) provides estimates of the responses of the total budget balance, and its structural and cyclical components to the output gap. Using the 
same methodology for South Africa, Table 6 shows estimates from bivariate regressions using the output gap as the independent variable and structural, cyclical and actual tax revenue, one at a time, as the dependent variable. The impact of the output gap on discretionary fiscal policy (measured by structural general government tax revenue) and automatic fiscal stabilisers (measured by cyclical general government tax revenue) varies significantly according to the chosen sample period. The role of automatic stabilisers was much smaller than that of discretionary fiscal policy over the sample period. Regressions over two sub samples (1970-1985 and 1986-2000) indicate that automatic fiscal stabilisers were stronger in the latter half of the sample period. Estimated effects of variations in the output gap on total tax revenue and structural tax revenue are not significant in any of the reported time periods.

\section{Table 6 Estimated response of tax revenue to the output gap}

\begin{tabular}{|c|c|c|c|}
\hline Sample period & $\begin{array}{c}\text { Structural } \\
\text { component }\end{array}$ & $\begin{array}{c}\text { Cyclical } \\
\text { component }\end{array}$ & Actual \\
\hline $\mathbf{1 9 7 0 - 2 0 0 0}$ & -1.14 & 0.12 & -1.03 \\
& $(1.81)$ & $(0.02)$ & $(1.80)$ \\
\hline $\mathbf{1 9 7 0 - 1 9 8 5}$ & 0.36 & 0.03 & 0.39 \\
& $(0.41)$ & $(0.00)$ & $(0.41)$ \\
\hline $\mathbf{1 9 8 6 - 2 0 0 0}$ & -2.35 & 0.19 & -2.16 \\
& $(3.39)$ & $(0.02)$ & $(3.37)$ \\
\hline $\mathbf{1 9 7 0 - 1 9 7 9}$ & -0.56 & 0.02 & -0.54 \\
& $(0.26)$ & $(0.00)$ & $(0.26)$ \\
\hline $\mathbf{1 9 8 0 - 1 9 8 9}$ & 1.39 & 0.07 & 1.46 \\
& $(0.90)$ & $(0.01)$ & $(0.91)$ \\
\hline $1990-2000$ & -4.27 & 0.22 & -4.05 \\
& $(4.55)$ & $(0.03)$ & $(4.53)$ \\
\hline
\end{tabular}

Note: Standard errors in parentheses

The regression results for the period 1970-1979 supports the findings of Heyns (1999) that the government relied strongly on discretionary policy action during the $1970 \mathrm{~s}$ in an attempt to smooth out automatic fluctuations in government deficits. This possibly explains the smaller automatic stabiliser estimates in the first half of the sample period illustrated in Figure 4. The larger coefficient of 0.22 of the cyclical component for the last decade (1990-2000) confirms the argument of Section 3.5 of GEAR that improvements in economic growth, apart from improved tax administration, should lead to a strong increase in tax revenue. Therefore, strong growth in tax revenue over the last few years can be ascribed to the working of automatic fiscal stabilisers in addition to better management and the implementation of more efficient procedures and practices 
by the South African Revenue Service. Thus, both these factors were an important force behind the success of the South African government in reducing the budget deficit over the past few years.

Figure 6 compares South Africa's output gap and cyclical tax revenue with six other developing countries, namely: Chile, India, Indonesia, Mauritius, Mexico and Romania. ${ }^{4}$ The size of South Africa ${ }^{*}$ s output gap is broadly similar to that of India, but smaller compared to the other countries. South Africa, India and Romania recorded their largest negative values in their output gaps in the early 1990s. Except for Indonesia, Mexico and Romania, the trend in cyclical tax revenue for each country is broadly similar to their respective output gaps. With the exception of Indonesia, there are not any major differences in the size of cyclical tax revenue between the various countries. Cyclical tax revenue in South Africa, India, Mexico and Romania reached their largest negative values in the early 1990s.

Table 7 A comparison of tax elasticities and tax to GDP ratios

\begin{tabular}{|l|c|c|c|c|}
\hline \multirow{2}{*}{ Country } & \multirow{2}{*}{ Elasticity } & \multicolumn{3}{|c|}{ Tax to GDP ratio } \\
\cline { 3 - 5 } & & Average & Maximum & Minimum \\
\hline Chile & 1.02 & 17.9 & 22.5 & 11.3 \\
\hline India & 1.01 & 9.8 & 11.0 & 8.0 \\
\hline Indonesia & 1.03 & 15.6 & 19.4 & 10.9 \\
\hline Mauritius & 1.55 & 6.7 & 10.3 & 2.0 \\
\hline Mexico & 1.03 & 12.7 & 15.4 & 8.1 \\
\hline Romania & 1.23 & 14.9 & 33.0 & 5.1 \\
\hline $\begin{array}{l}\text { South } \\
\text { Africa }\end{array}$ & 1.09 & 21.9 & 26.6 & 16.5 \\
\hline
\end{tabular}

Source: International Monetary Fund, Government Finance Statistics CD-ROM (August 2001) and WEO Database (October 2001); own calculations

The tax elasticity and tax to GDP ratio of each country are reported in Table 7. South Africa has the highest average tax to GDP ratio, followed by Chile and Indonesia. The South African minimum tax to GDP ratio is also the highest among the reported countries. Mauritius has the smallest average tax to GDP ratio and the lowest minimum. The highest maximum value of 33,0 per cent was recorded by Romania in 1992. Mauritius has the largest tax elasticity, followed by Romania and South Africa. 


\section{Figure 6 A comparison of output gaps and cyclical tax revenue ${ }^{5}$}

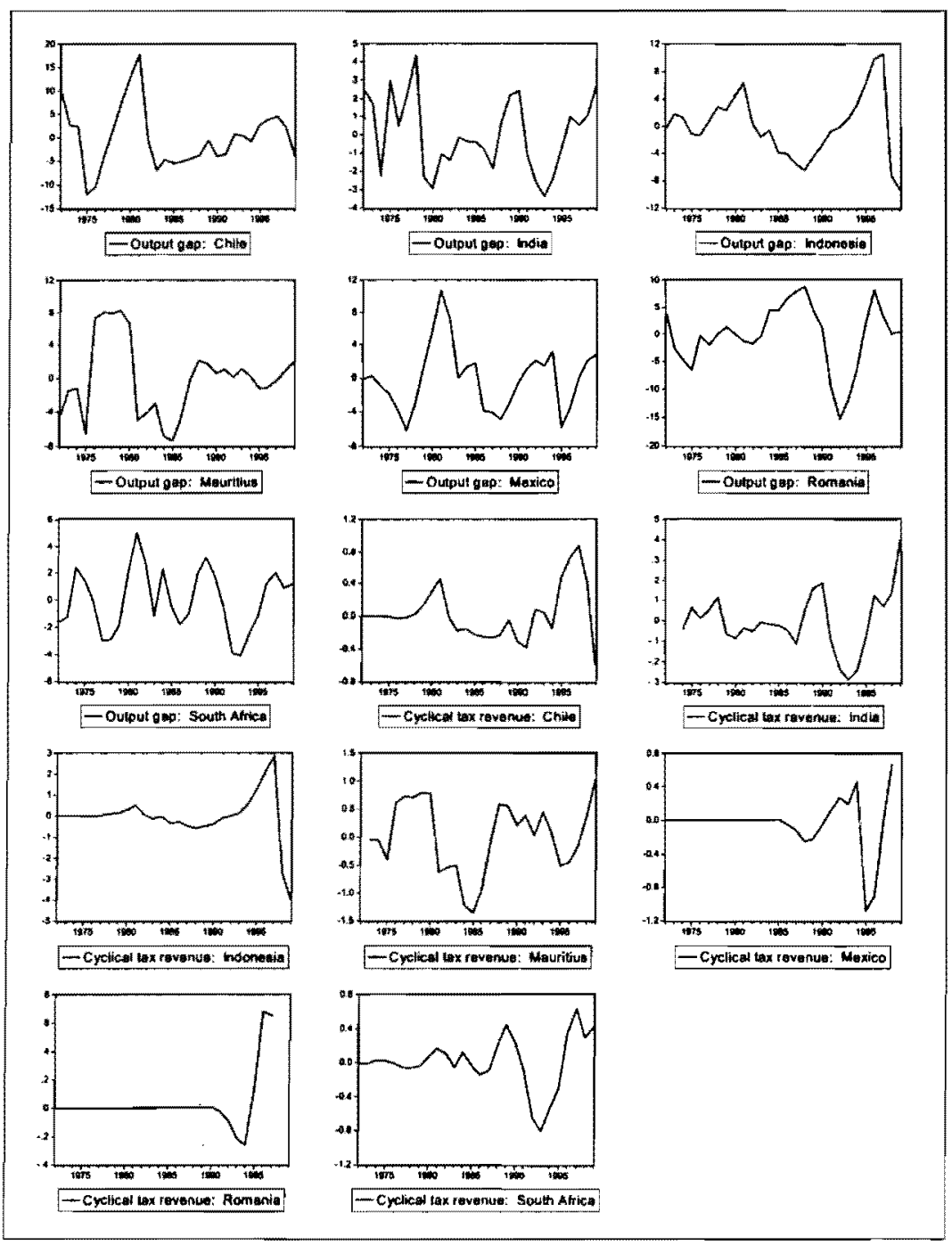

Source: International Monetary Fund, Government Finance Statistics CD-ROM (August 2001) and WEO Database (October 2001); own calculations 
South Africa must adopt an appropriate fiscal policy stance, taking the country's particular circumstances into account. Both fiscal discipline and flexibility are important. In fact, fiscal discipline and flexibility are complementary and interdependent features of budgetary behaviour. Fiscal discipline will allow the credibility of monetary policy to strengthen, while fiscal flexibility is required to deal with country-specific and other shocks. Since fiscal discipline is more or less confined in the South African government's GEAR strategy, it is in the latter case where automatic fiscal stabilisers can play an important role.

This article identified several factors that influence the size of automatic fiscal stabilisers. The main determinants of the size of automatic fiscal stabilisers associated with the tax system include the importance of the government sector in the economy, the tax structure, the progressivity of the tax system, the sensitivity of individual tax bases to the cycle, reforms in tax rates and structures and the distribution of income across individuals. Most of these factors are favourable in the South African context to allow automatic stabilisers to operate. The average tax to GDP ratio over the sample period was 23 per cent and the elasticity of general government tax revenue to GDP is 1.08. The marginal sensitivity of budgetary receipts was estimated at 0.2. The South African government's strategy on Growth, Employment and Redistribution (GEAR) is committed to preserve the fundamental progressiveness of the overall tax structure and states that the overall tax incidence of recent tax reforms has remained progressive. A graphical representation of tax revenue to GDP illustrated how South African tax revenue had grown in importance over the years. Increased tax revenue contributed to the annual reduction in the deficit and private dissaving over the past few years.

Over the last three decades, tax revenue was not affected much by variations in the output gap and the effects of cyclical responses to the output gap were relatively weak. The results show a small positive response of the automatic fiscal stabilisers to the output gap. Regressions over sub samples indicated the prominent role played by discretionary policy with deliberate attempts to smooth out automatic fluctuations during certain periods. Systematic and predictable responses through automatic stabilisers, with discretionary fiscal policy to be aimed at explicitly longer-term issues, requiring less frequent changes, can still be very important in the South African context. The automatic fiscal stabilisers became increasingly important since the 1990s. The results also show that automatic stabilisers in South Africa were employed symmetrically over the cycle, i.e. automatic fiscal stabilisers associated with the tax system operated in both the up and down phases of the cycle. Tax revenue responds more or less in line with changes in the output gap and the estimated automatic fiscal stabilisers 
also proofed to be relatively robust with respect to alternative assumptions of tax elasticities.

The article compared South Africa's cyclical tax revenue with six other developing countries, namely: Chile, India, Indonesia, Mauritius, Mexico and Romania. The size of South Africa's cyclical tax revenue is more or less in line with five of the six countries and the trend in cyclical tax revenue for most of the countries (including South Africa) is broadly similar to their respective output gaps. South Africa has the largest average tax to GDP ratio and a tax elasticity equal to the seven-country average.

It is important to note that automatic fiscal stabilisers are difticult to use in a policy framework as empirical estimates of the cyclical budget balance vary significantly. Different point-in-time output gap and elasticity estimates produce different point-in-time estimates of automatic stabilisers. Thus, relying on automatic stabiliser estimates for budgeting and decision-making purposes is difficult as a given budget deficit may be entirely cyclical (remedial action is not required) or entirely structural (remedial action required), depending on the assumptions. Also, the need to establish sufficient room for manoeuvre to allow automatic stabilisers to work is an important concern in setting medium-term targets. For positive gains to be realised, the tax system needs to be structured appropriately and questions such as whether the South A frican economy would benefit from adjustments in taxes to bring about stronger stabilisation must be addressed.

All the difficulties mentioned in Section 2 related to "fine tuning" the economy could be eliminated by properly functioning automatic fiscal stabilisers. However, before a proper assessment of the significance of automatic fiscal stabilisers in South Africa can be made, it is necessary to evaluate the automatic fiscal stabilisers on the expenditure side of the Budget as well. Moreover, apart from the traditional path of stabilisation through aggregate demand, other stabilisation paths such as stabilisation effects on labour supply should also be investigated.

\section{ENDNOTES}

1 Comprising the national government, extra-budgetary institutions and social security funds.

2 This article does not attempt to evaluate the strengths and weaknesses of different techniques to calculate potential output or to compare results for different sets of potential output and output gap estimates. In order to overcome the drawback of the poor reliability of the end of sample 
estimates associated with the HP filter, the GDP series was extended by forecasts based on GDP growth assumptions taken from the National Treasury's Budget Review 2002.

3 Note that these regressions show the average elasticity over the whole sample period and embody policy changes in addition to automatic effects. A correct measure of tax elasticities captures changes in tax revenue arising exclusively from changes in the tax base. Since no attempt was made to control for the impact of discretionary changes in the tax structure, the values reported should be interpreted as buoyancy coefficients rather than elasticities.

4. Data on tax revenue refer to the consolidated central government of each country.

5 As a ratio of trend GDP.

\section{REFERENCES}

1 ABEL, A.B. \& BERNANKE, B.S. (2001) Macroeconomics, (4th ed.) Boston: Addison Wesley Longman.

2 AUERBACH, A.J. \& FEENBERG, D. (2000) "The Significance of Federal Taxes as Automatic Stabilizers", NBER Working Paper No 7662.

3 BARRELL, R. \& PINA, A.M. (2000) "How Important are Automatic Stabilizers in Europe? A Stochastic Simulation Assessment", EUI Working Paper ECO No 2000/2.

4 BLANCHARD, O. (2000) "Commentary on Cohen and Follette", Federal Reserve Bank of New York Economic Policy Review, 6(1) 69-74.

5 CERRA, V. and SAXENA, S.C. (2000) "Alternative Methods of Estimating Potential Output and the Output Gap: An Application to Sweden", IMF Working Paper No 59.

6 COHEN, D. \& FOLLETTE, G. (2000) "The Automatic Fiscal Stabilizers: Quietly Doing their Thing", Federal Reserve Bank of New York Economic Policy Review, 6(1) 35-68.

7 EICHENGREEN, B. (1997) "Saving Europe's Automatic Stabilisers", National Institute Economic Review No 159.

8 EUROPEAN CENTRAL BANK (2002) "The Operation of Automatic Fiscal Stabilisers in the Euro Area", Monthly Bulletin, April, 33-46.

9 EUROPEAN COMMISSION (1997) Economic Papers, No 125.

10 GIORNO, C., RICHARDSON, P., ROSEVEARE, D. \& VAN DEN NOORD, P. (1995) "Potential Output, Output Gaps and Structural Budget Balances", OECD Economic Studies, No 24, 1995(1) 167-202.

11 HEYNS, JydS. (1999) "Fiscal Policy in South Africa During the 1970s", South African Journal of Economic History, Vol. 14(1\&2), September. 
12 HEYNS, JvdS. (1995) "The Dimension of Government Saving in South African Fiscal Policy", South African Journal of Economics, September.

13 ORGANIZATION FOR ECONOMIC CO-OPERATION AND DEVELOPMENT (1993) Automatic Stabilisers: Their Extent and Role, OECD Economic Outlook, No 53, 37-44.

14 ORGANIZATION FOR ECONOMIC CO-OPERATION AND DEVELOPMENT (1999) The Size and Role of Automatic Fiscal Stabilisers, OECD Economic Outlook, No 66, 137-149.

15 SOUTH AFRICA Budget Review, various issues. Pretoria. National Treasury.

16 SOUTH AFRICA (1996) Growth, Employment and Redistribution: A Macro-Economic Strategy. Pretoria: Department of Finance.

17 SOUTH AFRICAN RESERVE BANK Quarterly Bulletin, various issues.

18 SOUTH AFRICAN RESERVE BANK (2000) Annual Economic Report.

I9 TAM, J. \& KIRKHAM, H. (2001) "Automatic Fiscal Stabilisers: Implications for New Zealand", New Zealand Treasury Working Paper No 10. Wellington, New Zealand.

20 TAYLOR, J.B. (2000) "Reassessing Discretionary Fiscal Policy", Journal of Economic Perspectives, 14(3) 21-36.

21 VAN DEN NOORD, P. (2000) "The Size and Role of Automatic Fiscal Stabilizers in the 1990 s and Beyond", OECD Economic Department Working Paper No 230. 